\title{
Editorial
}

\section{The golden fifty and the glorious forthcoming}

\author{
n incredible journey!
}

The year 2018 marks the $50^{\text {th }}$ year of publication for Indian Journal of Plastic Surgery, which began in 1968. There cannot be a better occasion than this for me to assume the office of the Editor. Fifty years in publication is an important milestone and an outstanding achievement for any journal, particularly when the speciality did not even exist in most places.

Recollecting this glorious past is both nostalgic and an afflatus for all of us. In 1950, merely two plastic surgery units were functioning in India. In the next five years, the then five dedicated plastic surgeons in the country took the initiative to form an association with impetus from Sir Benjamin Rank, the pioneer of plastic surgery in Australia. Incidentally, the Australian association too had been formed with only five plastic surgeons. Thus, in 1957, the Association of Plastic Surgeons of India was formally inaugurated in Nagpur, by the legendary Sir Harold Gillies, with Dr R.N. Cooper as Founder President, Dr C. Balakrishnan(Vice President), Dr. R.N. Sinha (Founder Secretary), Dr M. Mukherji, Dr. R.N. Sharma and Dr N.H. Antia as Council members. ${ }^{[1]}$ The following decade saw magnanimous effort to start teaching units across the country, to get the speciality recognized by the Medical Council of India, and to formulate the curriculum. By 1968, there were 35 full members (with 31 associates), and eight teaching units at Patna, Calcutta, Lucknow, Delhi, Patiala, Chandigarh, Madras, and Bombay. ${ }^{[1]}$ It was at this juncture that, the birth of Indian Journal of Plastic Surgery (IJPS) took place, and Prof R. N Sinha, the dynamic founder secretary of the association took up the responsibility of being the Founder Editor. Dr Charles Pinto and $\operatorname{Dr} \mathrm{R} L$ Manchanda were founder members of the editorial team. The first issue (Vol. 1, No. 1) was published in July 1968, which was printed at Patiala, with the annual subscription of Rs. 25. This was a biannual publication and remained in the same frequency until a decade ago, after which, it became triannual.

Several doyens have laid a strong foundation, toiled, adopted, and nurtured this journal during these golden 50 years, to ensure uninterrupted publishing. Their tenacious efforts took the journal to the next level with each successive year. The notable scholars who held the baton of the Chief Editor include Prof R. N Sinha, Prof. Suresh Gupta, Prof. Rajinder Singh Tind, Prof. N. N. Khanna, Prof. Ramesh Chandra, Dr Rajan Bhiwapurkar, Dr. S. Raja Sabapathy, Prof. Pramod Kumar, Dr. Mukund Thatte, Dr. Surajit Bhattacharya and Prof. Mukund Jagannathan. Thanks to these eminent editors, today, the IJPS is widely read and accessible throughout the world.

The past issues of IJPS, rich in scientific temper with high quality articles, have remained largely unknown to the recent generations due to its limited access by the world across. Thanks to Dr Mukund Thatte who sent me soft copies of all previous issues, and we remain ever indebted to Prof Ramesh Chandra, who has diligently preserved each and every issue of this publication from its inception, that we now have the copies preserved for posterity. It is a treasure which chronicles the growth and progress of our association, academic work of our members, and the activities of our fraternity. It is our high priority to get these past publications archived and made available to the readers.

The journal today, enjoys excellent reputation and vast readership globally. We are steadily progressing, and a step away from Medline Indexing. Our model is unique and successful despite being absolutely non-commercial, as nothing is charged for either acceptance or for access.

The responsibility on the editorial team cannot be overemphasized. I have a new team of Deputy Editors joining me are: Dr Shivaram Bharatwaj (Chennai), Dr Atul Parashar (Chandigarh), Dr Nikhil Panse (Pune) and Dr Adhish Basu (Kolkata). Additionally, Dr Shailesh Ranade (Mumbai) is joining the team as Business editor to improve the finances of the journal. Our immediate priorities include an increase in the frequency of issues from three to four per year, theme issues on a regular basis, to aim at self-sufficiency in finances, and expedite the progress on our Indexing aspirations. My association with the journal for the last three years has been a prodigious learning experience, thanks to Prof Mukund Jagannthan, who has been my 
mentor in many ways. That legacy too will certainly help us in taking the journal a few steps further.

We need good quality original research papers and more experimental studies which are high on the pyramid of evidence based medicine. I therefore urge all of you to submit your work, and we assure you of due and prompt attention. This is your journal and it can only grow with your support and participation. We welcome your feedback and suggestions to help us perform better. We have a golden past and I look forward to an identically glorious future!

\section{Dinesh Kadam}

Editor IJPS, Professor and Head, Department of Plastic and Reconstructive Surgery,

A J Institute of Medical Sciences and A J Hospital and Research Centre, Mangalore, Karnataka, India E-mail: drkadam@yahoo.co.in

\section{REFERENCES}

1. Pinto C. Our association (Association of Plastic Surgeons of India). Indian J Plast Surg 1968;1:1-4.

This is an open access journal, and articles are distributed under the terms of the Creative Commons Attribution-NonCommercial-ShareAlike 4.0 License, which allows others to remix, tweak, and build upon the work non-commercially, as long as appropriate credit is given and the new creations are licensed under the identical terms.

\begin{tabular}{|l|l|}
\hline \multicolumn{2}{|c|}{ Access this article online } \\
\hline Quick Response Code: & Website: \\
\hline
\end{tabular}

How to cite this article: Kadam D. The golden fifty and the glorious forthcoming. Indian J Plast Surg 2018;51:1-2. 